Bawden, F. C. \& Freeman, G. G. (1952). J. gen. Microbiol. 7, 154-168

\title{
The Nature and Behaviour of Inhibitors of Plant Viruses produced by Trichothecium roseum Link
}

\author{
By F. C. BAWDEN AND G. G. FREEMAN \\ Rothamsted Experimental Station, Harpenden, Hertfordshire and Imperial Chemical \\ Industries Limited, Nobel Division, Research Department, Stevenston, Ayrshire
}

SUMMARY: Culture filtrates of Trichothecium roseum contain two heat-stable substances that inhibit infection with plant viruses. One is trichothecin, an antifungal substance with the molecular formula $\mathrm{C}_{19} \mathrm{H}_{24} \mathrm{O}_{5}$; it sometimes visibly damages bean leaves. The other was isolated as a polysaccharide, $[\alpha]_{D}^{19^{\circ}}=-\mathbf{3 3}^{\circ}$; it contains $1 \cdot 1-1 \cdot 4 \%$ nitrogen, yields $60-70 \%$ reducing sugars (as glucose) on acidic hydrolysis, and the predominant (45\%) component sugar is D-galactose. The polysaccharide does not combine with tobacco mosaic virus in vitro.

The extent to which infection is inhibited depends on the species of the host plant but not on the identity of the virus. Trichothecin, like ribonuclease, is relatively more effective with beans than with Nicotiana glutinosa, whereas the polysaccharide and two derivatives of trichothecin (trichothecolone and acetyltrichothecolone) affect $N$. glutinosa more than beans. Trichothecin inhibits infection when sprayed over leaves a day after they have been inoculated with viruses, but is ineffective when applied 2 days before. The polysaccharide inhibits when sprayed over leaves before inoculation but not after. It is suggested that inhibitors act by temporarily altering the metabolism of leaf cells so that introduced virus particles cannot multiply and are inactivated.

The infectivity of plant virus solutions can be inhibited by extracts from many different kinds of organism. The responsible substances mostly remain unidentified, but it is known that inhibitors can have widely different chemical compositions. For example, among the inhibitors most studied are the two pancreatic enzymes, trypsin (Caldwell, 1933; Stanley, 1934) and ribonuclease (Loring, 1942), a polysaccharide from yeast (Takahashi, 1942, 1946), and a glycoprotein from Phytolacca esculenta (Kassanis \& Kleczkowski, 1948). Weight for weight, these substances have different activities, but all share some features. They do not obviously damage the host plants; infectivity is inhibited immediately they are mixed with the virus solutions, and it can be restored partly or wholly by diluting the mixtures or removing the inhibitor.

Whether inhibitors act by affecting the viruses or the host plants has been much debated, but remains undecided. Stanley (1934) concluded that trypsin was most likely affecting the plant, but he could find no evidence that the enzyme and virus combined in vitro. Not only trypsin (Bawden \& Pirie, 1936; Hills \& Vinson, 1938; Kleczkowski, 1944) but also the more powerful inhibitors, ribonuclease (Loring, 1942; Kleczkowski, 1946) and the phytolacca glycoprotein (Kassanis \& Kleczkowski, 1948), are now known to combine with plant viruses when mixed with them at $\mathrm{pH}$ values around neutrality. This provides a ready explanation for inhibition, because the combination might block specific groups on the viruses that need to combine with receptors in the host cell as a first step in infection. However, as Kassanis \& Kleczkowski 
(1948) pointed out, the results of infectivity tests with mixtures of virus and inhibitor, do not fit a simple quantitative neutralization, such as occurs when toxins and anti-toxins are mixed; in particular, there is no constant ratio of inhibitor to virus that wholly neutralizes infectivity, and the greater the concentration of virus in the inoculum, the smaller is the ratio of inhibitor to virus that is needed to prevent any infections. Thus, although these inhibitors combine with viruses in vitro, combination may be incidental to inhibition, which may occur for other reasons. That inhibitors may act on the host plant is suggested by the lack of evidence for any specific action between them and individual viruses, whereas there is some evidence that they may affect different hosts to different extents. For example, in tests with tobacco mosaic virus, trypsin (Stanley, 1934) and ribonuclease (Loring, 1942) more effectively prevented infection of Phaseolus vulgaris than of Nicotiana glutinosa; also, inhibitors occurring in leaves of some plants prevent the infection of other species but not of the species from which they come (Bhargava, 1951; van der Want. 1951). Such evidence, however, is inconclusive, because different plants might differ in their ability to split non-infective complexes of viruses and inhibitors.

Since Johnson (1938) showed that Aerobacter aerogenes and Aspergillus niger produce inhibitors of plant viruses, many bacteria and fungi have been found to do so, but only with yeast has there been any attempt to identify the responsible substance (Takahashi, 1942, 1946). Gupta \& Price (1950) tested filtrates of forty-nine species of fungi and found that more than three-quarters of them caused some inhibition. Filtrates of Trichothecium roseum and Neurospora sitophila were the most powerful inhibitors, and experiments with the first led Gupta \& Price to conclude that the substance responsible was thermostable and non-dialysable. Their data did not fully substantiate the conclusion that inhibitory power was unaffected by dialysis, for dialysed filtrates inhibited less than others, but the tests were not made in conditions that enabled the significance or the extent of the loss to be estimated accurately. None of their results necessitated the conclusion that only one substance was causing inhibition, and it seemed possible that growth products of different sizes might be concerned.

Trichothecium roseum is antagonistic towards various fungi which are pathogenic to plants (Whetzel, 1909). The substance responsible was isolated and called trichothecin by Freeman \& Morrison $(1949 a, b)$, and Freeman \& Gill (1950) showed it to be the isocrotonyl ester $\left(\mathrm{C}_{19} \mathrm{H}_{24} \mathrm{O}_{5}\right)$ of the ketonic alcohol, trichothecolone $\left(\mathrm{C}_{15} \mathrm{H}_{20} \mathrm{O}_{4}\right)$. Other metabolic products, rosein I, II and III, were also isolated (Freeman, Morrison \& Michael, 1949; Robertson, Smithies \& Tittensor, 1949). The work we describe was started to find whether any of these products interfere with the ability of plant viruses to cause infection. Trichothecin does so, but is responsible for only part of the inhibitory power of filtrates, most of which is caused by a polysaccharide, whose isolation and properties are described. 


\section{MATERIALS AND METHODS}

Infectivity tests were made with viruses and hosts that give countable necrotic local lesions. Most were made with tobacco mosaic virus in N. glutinosa $\mathrm{L}$. and the Rothamsted culture of tobacco necrosis virus in French bean ( $P$. vulgaris L., var. Prince); some were also made with tobacco mosaic virus in a hybrid tobacco and in $P$. vulgaris, var. Riscardo do Milho, with the tobacco necrosis virus in $N$. glutinosa and the hybrid tobacco, and with tomato bushy stunt virus in $N$. glutinosa. Purified virus preparations were used; those of tobacco mosaic and tomato bushy stunt viruses were made by precipitation methods and of the tobacco necrosis virus by ultracentrifugation. Solutions in water of the substances to be tested were mixed with virus solutions and inoculated to at least six half-leaves. In each experiment, the different treatments were distributed over the test plants in the form of Latin squares or incomplete blocks. Inoculations were made by rubbing half-leaves with the forefinger wetted with the inoculum; the leaves were not washed after inoculation. In some experiments, solutions of the substances were not mixed with the viruses, but were sprayed over whole leaves by means of a glass atomizer.

$T$. roseum, strain F 292, was grown, unless otherwise stated, on the medium described by Freeman \& Morrison (1949a), which contains $1 \%$ corn steep liquor, $5 \%$ commercial glucose and $\mathbf{0 . 2} \%$ ammonium tartrate. Undiluted corn steep liquor inhibited infection with the viruses and damaged inoculated leaves, but the complete medium did not. The trichothecin content of filtrates was assayed by measuring the extent to which the germination of spores of Penicillium digitatum was inhibited.

Nitrogen was determined by the micro-Kjeldahl method and reducing sugars by Hanes's modification of the Somogyi (1937) method (see Hockenhull $\&$ Herbert, 1945). Ribonuclease was estimated by determining the extent to which yeast nucleic acid was rendered unprecipitable by acetic acid after $3 \mathrm{hr}$. incubation at $\mathrm{pH} 6.5$ and $50^{\circ}$ (Kleczkowski, 1946).

\section{EXPERIMENTAL}

\section{Inhibition by substances with small molecular weights}

Preliminary tests with solutions of crystalline preparations of trichothecin (Freeman \& Morrison, 1949 a) and rosein I, II and III (Freeman, et al. 1949) showed that trichothecin at concentrations of $20 \mathrm{mg}$./l. or higher inhibited infection of French bean by the tobacco necrosis virus and of $N$. glutinosa by tobacco mosaic virus, whereas the roseins had no effect. The extent to which trichothecin decreased the numbers of local lesions varied considerably in different experiments. Usually it inhibited more with tobacco necrosis virus in beans than with tobacco mosaic virus in $N$. glutinosa. On average, in experiments when control inocula produced from 30-70 lesions/half-leaf, trichothecin at $100 \mathrm{mg}$. $/ 1$. decreased numbers of lesions to about one-third or a quarter with beans, and to one-half with $N$. glutinosa (Tables 1-3), but the 
decrease varied considerably in different experiments. The variation was correlated with the physiological condition of the test plants, and, in general. the more susceptible the plants, particularly beans, were to infection, the more trichothecin decreased the numbers of infections. At concentrations of $50 \mathrm{mg}$./l. or higher, trichothecin often caused obvious damage to bean leaves, but it rarely did so to $N$. glutinosa even at $200 \mathrm{mg}$./l. Gupta \& Price (1950) found that undiluted filtrates from cultures of $T$. roseum 'caused visible burning of the leaves', an effect that seems attributable solely to the trichothecin present. Solutions of crystalline trichothecin caused the same damage as culture filtrates of the same trichothecin content, and filtrates from which trichothecin was removed caused none. In our tests with beans, trichothecin at $100 \mathrm{mg}$./l. sometimes had no macroscopic effects, sometimes caused scattered necrotic spots, and sometimes caused extensive necrosis, areas of 1 sq.cm. or more collapsing. Except that no lesions developed in such collapsed areas, the extent to which leaves were damaged and infection was inhibited were not obviously correlated. The number of lesions was often much decreased in bean leaves which showed little or no injury.

Table 1. Effect of trichothecin and its derivatives on infection

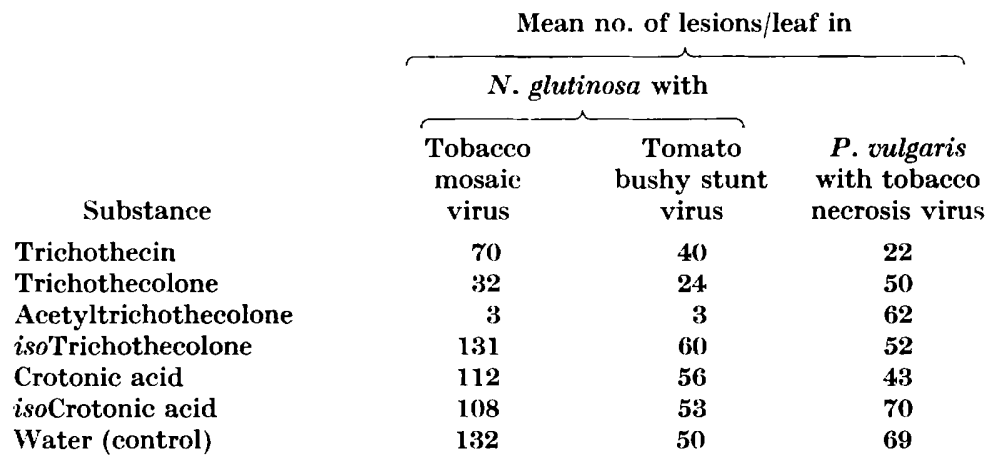

Inoculations were made with substances at $100 \mathrm{mg} . / 1$. and the viruses at $2.5 \mathrm{mg} . / \mathrm{l}$.

In addition to tests with metabolic products of $T$. roseum, some were also made with derivatives of trichothecin (Freeman \& Gill, 1950). The results of one series of tests are given in Table 1 . which shows that trichothecolone and acetyltrichothecolone inhibited infection. In sharp contrast to trichothecin, both these more effectively prevented infection of $N$. glutinosa than of beans. Both substances, but the acetyl derivative more strikingly, also showed a reverse action to that of trichothecin, in causing damage to $N$. glutinosa leaves but not to bean leaves. Thus the introduction of different groups into these substances can entirely change their behaviour towards different plants, and there is a clear suggestion that ability to inhibit infection by viruses may be correlated with ability to interfere with the metabolism of the host plant. 


\section{Inhibition with non-dialysable substances}

The fact that trichothecin is not the only substance in culture filtrates of $T$. roseum that inhibits infection with plant viruses was readily demonstrated by comparing the inhibition caused by untreated filtrates with that caused by dialysed filtrates and by water solutions of trichothecin. Table 2 shows the summarized results of tests with a filtrate that initially had a total solid content of $30 \mathrm{~g} . / \mathrm{l}$., of which $130 \mathrm{mg} . / \mathrm{l}$. was trichothecin. After dialysis, for 1 day against tap-water and 1 day against distilled water, the trichothecin content, assayed biologically, was less than $1 \mathrm{mg} . / 1$., and the total solid content was $2.5 \mathrm{~g}$. $/ \mathrm{l}$. The crude filtrate was a much stronger inhibitor than water solutions of equal trichothecin content, as also was the dialysed filtrate in tests with $N$. glutinosa. When trichothecin was added to the dialysed filtrate, in an amount equal to that present in the original filtrate, the original inhibitory and leaf-damaging actions were fully restored, suggesting that trichothecin is the only dialysable product of the fungus with these actions.

Table 2. Inhibiting effects of trichothecin and dialysed filtrate

\begin{tabular}{|c|c|c|c|}
\hline \multirow[b]{2}{*}{ Inhibitor } & \multicolumn{3}{|c|}{ No. of lesions/leaf with } \\
\hline & $\begin{array}{c}\text { Tobacco } \\
\text { mosaic } \\
\text { virus in } \\
N \text {. glutinosa }\end{array}$ & $\begin{array}{c}\text { Tobacco } \\
\text { necrosis } \\
\text { virus in } \\
\text { N. glutinosa }\end{array}$ & $\begin{array}{c}\text { Tobacco } \\
\text { necrosis } \\
\text { virus in } \\
\text { beans }\end{array}$ \\
\hline Culture filtrate $10 / 13$ & 1 & 1 & 10 \\
\hline Dialysed filtrate $10 / 13$ & 2 & 4 & 20 \\
\hline Trichothecin $100 \mathrm{mg} . / \mathrm{l}$. & 45 & 23 & 27 \\
\hline $\begin{array}{l}\text { Dialysed filtrate } 10 / 13 \\
\text { Trichothecin } 100 \mathrm{mg} . / 1 .\end{array}$ & $\mathbf{1}$ & 2 & 9 \\
\hline Water (control) & 155 & 101 & 78 \\
\hline
\end{tabular}

Inhibitors were mixed with equal volumes of virus solutions; tobacco mosaic virus at $5 \mathrm{mg}$./l., tobacco necrosis at $2 \mathrm{mg}$./l. for test in beans and $10 \mathrm{mg}$./1. for test in $\mathbf{N}$. glutinosa.

Table 2 shows that removing trichothecin from the filtrate had little effect on the extent to which infection of $N$. glutinosa was inhibited, and that the dialysed filtrate was relatively more effective in decreasing numbers of infections in this host than in beans. The similar results from tests with tobacco mosaic and tobacco necrosis viruses in $N$. glutinosa suggest that the identity of the host plant rather than that of the virus determines the extent to which infection is inhibited. That this is so, has been confirmed repeatedly. When mixed with trichothecin or dialysed filtrate and inoculated to $N$. glutinosa, tomato bushy stunt virus gives results that closely parallel those with tobacco mosaic and tobacco necrosis virus in this host. In beans, tobacco mosaic virus behaves like tobacco necrosis virus; that is to say, trichothecin is relatively more effective in inhibiting infection than it is in $N$. glutinosa, whereas the dialysed filtrate is relatively less effective. In tests with the dialysed filtrate and hybrid tobacco plants, similar results are obtained with both tobacco mosaic and tobacco necrosis viruses, and inhibition is intermediate between that obtained with $N$. glutinosa and beans. 
Gupta \& Price (1950) found that infection of beans by southern bean mosaic virus was inhibited when leaves were rubbed with $T$. roseum culture filtrate $30 \mathrm{~min}$. after inoculation with the virus. We have made no tests in which leaves were rubbed twice, as this damages the leaves and itself decreases numbers of infections, but have made many in which whole leaves were sprayed with solutions at different times before and after they were inoculated with viruses. These showed that infection can be inhibited when the delay between inoculating with virus and applying culture filtrate is much more than 30 min., and that trichothecin and the non-dialysable component behave very differently when applied at intervals before and after inoculating with

Table 3. Effect of spraying bean leaves with trichothecin and dialysed filtrate before and after inoculation with tobacco necrosis virus

$\begin{array}{lcc}\text { Time of spraying } & \overbrace{\text { Trichothecin }}^{\text {No. of lesions/leaf when sprayed with }} & \begin{array}{c}\text { Dialysed } \\ \text { filtrate }\end{array} \\ \text { 3 days before inoculation } & 290 & 150 \\ \text { 2 days before inoculation } & 230 & 140 \\ \text { 1 day before inoculation } & 118 & 120 \\ \text { Unsprayed } & 300 & 245 \\ \text { 1 hr. after inoculation } & 33 & 234 \\ \text { 4 hr. after inoculation } & 51 & \mathbf{2 4 0} \\ \text { 1 day after inoculation } & 82 & \mathbf{2 8 5}\end{array}$

Table 4. Effect of spraying N. glutinosa leaves with trichothecin and dialysed filtrate before and after inoculation with tobacco mosaic virus

\begin{tabular}{|c|c|c|}
\hline \multirow[b]{2}{*}{ Time of spraying } & \multicolumn{2}{|c|}{ No. of lesions/leaf when sprayed with } \\
\hline & $\begin{array}{l}\text { Trichothecin } \\
\text { (100 mg./l.) }\end{array}$ & $\begin{array}{l}\text { Dialysed } \\
\text { filtrate }\end{array}$ \\
\hline 1 day before inoculation & 26 & 11 \\
\hline $1 \mathrm{hr}$. before inoculation & 33 & 2 \\
\hline Unsprayed & 70 & 54 \\
\hline $1 \mathrm{hr}$. after inoculation & 26 & 44 \\
\hline $4 \mathrm{hr}$. after inoculation & 33 & 52 \\
\hline 24 hr. after inoculation & 35 & 61 \\
\hline
\end{tabular}

virus. Some of the differences are illustrated in Tables 3 and 4 . When sprayed on the leaves 2 or 3 days before they are inoculated, trichothecin causes little or no inhibition; sprayed a day before, it decreases the numbers of lesions, although less so than when sprayed up to 1 day after inoculation. By contrast, the non-dialysable component has little or no effect when sprayed on the leaves an hour after inoculation, whereas all the pre-inoculation sprayings inhibit infection, the effect decreasing only slowly with increasing delay between spraying and inoculation.

The different behaviour of the two inhibitors was further shown when solutions were sprayed over either the upper or lower surfaces of leaves which were inoculated on their upper surfaces an hour before or after the sprayings. In tests with $N$. glutinosa and tobacco mosaic virus, dialysed filtrate inhibited 
strongly only when the upper surfaces were sprayed before inoculation, whereas with beans and the tobacco necrosis virus all four sprayings with trichothecin inhibited infections equally strongly. Such differences in behaviour of the two inhibitors are most likely attributable simply to differences in their size. The small molecules of trichothecin can presumably penetrate uninjured leaves and diffuse readily from cell to cell, whereas the non-dialysable inhibitor, like a virus, needs a wound through which to enter. Within an hour of being rubbed with water, leaves recover sufficiently from their injuries to prevent infection when they are sprayed with virus solutions (Kalmus \& Kassanis, 1945). This rapid healing probably explains the short period after inoculation during which spraying with the dialysed filtrate inhibits infection. Its relatively lasting effect when applied before inoculation suggests that it persists unchanged on the sprayed leaves until they are rubbed and that such substances might be economically useful as preventive sprays.

Of more interest in understanding the mechanism of inhibition is the transitory effect of trichothecin when applied before inoculation. It seems that, on entering cells, it changes them in such a manner that infection with viruses is prevented. The changes are temporary and, after a day or so, the cells return to normal, at least in their susceptibility to infection with viruses. Trichothecin decreases the number of infections when it is applied a day after leaves have been inoculated with tobacco necrosis virus. As visible lesions appear in 2-3 days after inoculation, it seems that the changes caused by trichothecin are such that, even in cells where infection is already established, the virus can still be prevented from multiplying sufficiently to cause a lesion.

Gupta \& Price (1950) found that boiled culture filtrates of $T$. roseum inhibited infection and concluded that the inhibitor was not a protein. However, as ribonuclease resists boiling at $\mathrm{pH} 6$, this conclusion is not necessarily valid. The need for further evidence was emphasized by the fact that the first culture filtrate we studied depolymerized yeast nucleic acid. Comparisons with solutions of pancreatic ribonuclease suggested that the enzyme content was too small to account for more than a little of the inhibitory power, and showed that ribonuclease behaved differently from dialysed filtrate in that it inhibited infection of beans much more strongly than infection of $N$. glutinosa (Table 5). Further differences between the two were also demonstrated by boiling at different $\mathrm{pH}$ values. Boiling for $10 \mathrm{~min}$. at either $\mathrm{pH} 6$ or 8 leaves the inhibitory power of the dialysed filtrate unimpaired; indeed, in many tests it was slightly enhanced, suggesting that heating may have destroyed some component that interferes with its action. Boiling at $\mathrm{pH} 8$ destroys ribonuclease activity (Kleczkowski, 1946) and largely destroys its ability to inhibit infection of $N$. glutinosa, the host more sensitive to dialysed filtrate; ability to inhibit infection of beans, the host less sensitive to dialysed filtrate, is lessened but not destroyed (Table 5).

These results virtually excluded the possibility that the dialysed filtrates inhibit because they contain a protein resembling pancreatic ribonuclease. For the ribonuclease in the filtrate to be responsible, it would need to differ from pancreatic ribonuclease in its resistance to boiling and its relative action 
Table 5. Effect of boiling on inhibitory power of dialysed

filtrate and ribonuclease

\begin{tabular}{|c|c|c|c|}
\hline \multirow[b]{2}{*}{ Solution } & \multicolumn{3}{|c|}{ No. of lesions/leaf with } \\
\hline & $\begin{array}{c}\text { Tobacco } \\
\text { necrosis } \\
\text { virus in } \\
\text { beans }\end{array}$ & $\begin{array}{c}\text { Tobacco } \\
\text { mosaic } \\
\text { virus in } \\
\text { N. glutinosa }\end{array}$ & $\begin{array}{c}\text { Tomato } \\
\text { bushy stunt } \\
\text { virus in } \\
N . \text { glutinosa }\end{array}$ \\
\hline Dialysed filtrate $1 / 2$ & 32 & 7 & 5 \\
\hline Boiled dialysed filtrate $1 / 2$ & 24 & 6 & 2 \\
\hline Ribonuclease $0.01 \%$ & 0.5 & 8 & 7 \\
\hline Boiled ribonuclease $0.01 \%$ & 20 & 112 & 153 \\
\hline M/30 Phosphate buffer & 85 & 150 & 208 \\
\hline
\end{tabular}

Dialysed filtrate and pancreatic ribonuclease were boiled for $10 \mathrm{~min}$. at $\mathrm{pH} 8$ in $\mathrm{M} / 30$ phosphate buffer, and brought to $\mathrm{pH} z$ before mixing with virus solutions at $5 \mathrm{mg} . / \mathrm{l}$.

towards beans and $N$. glutinosa. That it is not responsible was shown by later work with other batches of culture filtrates and, more particularly, with fractions from them, which inhibited infectivity strongly but had no detectable ribonuclease activity and probably contained no protein.

\section{Purification of the non-dialysable inhibitor}

As a preliminary to attempting the isolation of the non-dialysable inhibitor, the growth of $T$. roseum was studied on media containing fewer initial components with large molecules than that used for trichothecin production. Instead of $50 \mathrm{~g}$. commercial glucose/l. as used by Freeman \& Morrison (1949a), $40 \mathrm{~g}$. pure glucose/l. were used, and instead of $10 \mathrm{ml}$. corn steep liquor/l. a range from 10 to $0 \mathrm{ml}$. was tried, and compared with $10 \mathrm{ml} . / 1$. of the diffusate fraction from dialysed corn steep liquor. T. roseum grew slowly for the first 14 days on the medium containing no corn steep liquor, but on the others growth resembled that on the usual medium. At the end of 28 days the trichothecin content varied from $66 \mathrm{mg}$./l. in the culture on medium containing $10 \mathrm{ml}$. corn steep liquor $/ \mathrm{l}$. to $18 \mathrm{mg}$./ $\mathrm{l}$. for the medium free from corn steep liquor. All the culture filtrates strongly inhibited infection of $N$. glutinosa by tobacco mosaic virus, showing that the non-dialysable inhibitor was produced in satisfactory amounts in media containing pure glucose and diffusate from corn steep liquor; the culture on medium free from corn steep liquor was the least effective inhibitor, probably because of its slow growth.

The first fractionation was made with 71 . of culture filtrate harvested after T. roseum had grown for 28 days on a medium containing $1 \%(\mathrm{v} / \mathrm{v})$ of diffusate from dialysed corn steep liquor. The filtrate, which contained $42 \mathrm{mg}$. trichothecin/l., was concentrated to $500 \mathrm{ml}$. by evaporation in vacuo, and then dialysed for 1 day against tap water and 1 day against distilled water. After removing a small precipitate by filtration, the fluid was concentrated to $100 \mathrm{ml}$. by further evaporation in vacuo. After removing a little insoluble material by centrifugation, the solid content of the fluid was $42 \cdot 4 \mathrm{~g}$./1.; the trichothecin content was $37 \mathrm{mg} . / \mathrm{l}$., showing that $99 \%$ of that originally 
present was removed by dialysis. Infectivity tests with tobacco mosaic virus in $N$. glutinosa showed that little of the non-dialysable inhibitor was lost during these treatments.

The concentrated dialysed filtrate had an apparent glucose content of $1.1 \mathrm{~g}$. $/ 1$. before hydrolysis and of 25.5 and $26.5 \mathrm{~g}$./l. after hydrolysis with $2 \mathrm{~N}-\mathrm{H}_{2} \mathrm{SO}_{4}$ for 2 and $4 \mathrm{hr}$. respectively. The addition of an equal volume of $10 \%$ trichloroacetic acid separated a precipitate, equal to $1.2 \mathrm{~g}$. from a litre. This material caused little inhibition and the inhibitory power of the filtrate was only slightly decreased by its removal. The addition of 5 vols. of ethanol precipitated crude polysaccharide amounting to $31 \mathrm{~g} . / \mathrm{l}$. of concentrated filtrate. This precipitate contained the bulk of the inhibitor, though some remained in the ethanolic mother liquor, which also still contained some carbohydrate.

These preliminary tests showed that the inhibitor could be dried in vacuo and redissolved without losing activity, and suggested that it was associated with polysaccharide, a major component of the filtrate, and not with the minor protein component. This was further suggested by tests in which the concentrated filtrate was treated according to the Sevag method for removing protein. After removing a little insoluble material (fraction B27/29a), the filtrate was twice shaken with chloroform (Sevag, Lackman \& Smolens, 1938). A little chloroform gel was produced, which was freed from chloroform and extracted with $50 \mathrm{ml}$. water $(\mathrm{B} 27 / 29 b)$. The aqueous supernatant fluid from the chloroform treatment was then fractionally precipitated with increasing strengths of ethanol to yield the five polysaccharide fractions B 27/29 (1)-(5), and the ethanolic mother liquor B27/29 (6). A little glacial acetic acid was added during the precipitation to facilitate flocculation.

The yields and properties of the fractions are shown in Table 6. The different fractions differ in nitrogen contents and amounts of reducing sugars yielded by hydrolysis. If it can be accepted that the chloroform treatment removed all protein, it can be assumed that the polysaccharide contains nitrogen and that infectivity is inhibited by polysaccharide. The fraction precipitated by $50 \%$ (w/w) ethanol is, weight for weight, less active as an inhibitor than the others, but the fractions do not separate sharply into those that inhibit infectivity and those that do not.

Similar results were obtained with two other batches of culture filtrate, one of $13 \mathrm{l}$. from a medium containing no corn steep liquor and one of $15 \mathrm{l}$. from a medium containing $1 \%(\mathrm{v} / \mathrm{v})$ of diffusate from dialysed corn steep liquor. After concentration by evaporation in vacuo, dialysis and twice shaking with chloroform, precipitation with $80 \%(\mathrm{w} / \mathrm{w})$ ethanol gave precipitates of crude polysaccharide amounting to 0.27 and $0.54 \mathrm{~g}$. $/ 1$. of initial culture filtrate, the mean yield for the three isolations being $0.41 \mathrm{~g} . / \mathrm{l}$. The protein fractions separated by the treatment with chloroform accounted for less than $5 \%$ of the inhibitory power, which can be attributed to polysaccharide occluded in the protein-chloroform gel. The bulk of the activity was in the precipitate separated by ethanol, but some remained in the ethanolic mother liquor, which also contained polysaccharide. 
The crude polysaccharide was precipitated with $80 \%$ ethanol and redissolved in water five times, and then treated with decolorizing charcoal and filtered. When treated with increasing strengths of ethanol between 50 and $80 \%(w / w)$, the polysaccharide again produced a series of fractions all of which inhibited infectivity, contained from $1 \cdot 1$ to $1.8 \%$ nitrogen, and

Table 6. Properties of polysaccharide fractions

\begin{tabular}{|c|c|c|c|c|c|}
\hline Fraction & $\begin{array}{c}\text { Fraction } \\
\text { precipitated } \\
\text { at ethanol } \\
\text { concen- } \\
\text { tration } \\
(\%, w / w)\end{array}$ & $\begin{array}{c}\text { Yield of } \\
\text { fraction } \\
(\mathrm{g} .)^{*}\end{array}$ & $\begin{array}{c}\text { lijeldahl } \\
\text { nitrogen } \\
\left(\begin{array}{c}0 \\
0\end{array}\right)\end{array}$ & $\begin{array}{l}\text { Reducing } \\
\text { value as } \\
\text { glucose after } \\
\text { hydrolysis } \\
\text { for } 3 \mathrm{hr} \text {. } \\
\text { with } 2 \mathrm{~N} \\
\text { sulphuric } \\
\text { acid at } \\
100^{\circ} \\
(\%)\end{array}$ & $\begin{array}{l}\text { No. of } \\
\text { lesions per } \\
\text { leaf with } \\
\text { tobacco } \\
\text { mosaic } \\
\text { virus in } \\
N \text {. glutinosa }\end{array}$ \\
\hline $\begin{array}{l}\text { Insoluble residue, B27/29a } \\
\text { Ethanolic fractions: }\end{array}$ & - & $0 \cdot 080$ & -- & -- & -- \\
\hline $\mathrm{B} 27 / 29(1)$ & 50 & 0.198 & $2 \cdot 4$ & $49 \cdot 6$ & 10 \\
\hline $\mathrm{B} 27 / 29(2)$ & 60 & $0.61 \%$ & $1 \cdot 5$ & $59 \cdot 9$ & $1 \cdot 6$ \\
\hline $\mathrm{B27} / 29(3)$ & 66 & 0.438 & $1 \cdot 2$ & $63 \cdot 6$ & $1 \cdot 3$ \\
\hline $\mathrm{B27} / 29$ (4) & 75 & 0.247 & $0 \cdot 9$ & $53 \cdot 7$ & $0 \cdot 6$ \\
\hline $\mathrm{B} 27 / 29(5)$ & 80 & $0 \cdot 058$ & $1 \cdot 7$ & $48 \cdot 5$ & $1 \cdot 3$ \\
\hline $\left.\begin{array}{l}\mathrm{B27} / 29(6) \\
\text { (Mother liquor) }\end{array}\right\}$ & - & $0 \cdot 441$ & - & - & 2 \\
\hline 'Protein' B27/29b & -- & 'Trace & - & - & 10 \\
\hline Water (control) & - & - & 一 & - & 97 \\
\hline
\end{tabular}

yielded from 50 to $\mathbf{7 0} \%$ reducing sugars after acid hydrolysis. Again, the fraction precipitated by $50 \%(\mathrm{w} / \mathrm{w})$ ethanol was the least effective inhibitor and had the highest nitrogen content. The more active fractions precipitated in the range $60-75 \%(\mathrm{w} / \mathrm{w})$ ethanol contained between 1.1 and $1.5 \%$ nitrogen and yielded 60-70\% apparent glucose after acid hydrolysis.

The similarity in behaviour of the polysaccharides separated from the different batches of culture filtrate suggests that there was no gross heterogeneity in the preparations, but there is insulficient evidence to show whether they consist of a single form or of a mixture of similar though not identical types. It seems likely that a variety of different polysaccharides can inhibit infection with plant viruses, and that the inhibitors produced by many fungi and bacteria are polysaccharides. The polysaccharide obtained from yeast by Takahashi (1946) seems to differ from that produced by $T$. roseum. Similarly, other polysaccharides from a species of Rhizobium, supplied to us by Dr A. Kleczkowski, and from several species of basidiomycetous fungi, supplied to us by Mr M. V. Tracey, have all inhibited infection of $N$. glutinosa by tobacco mosaic virus. 
Nature of component sugars of the polysaccharide inhibitor

The polysaccharide fractions precipitated by $60-75 \%(w / w)$ ethanol were almost colourless powders which dissolved readily in water to give clear pale yellow solutions at concentrations of $20 \mathrm{~g} . / \mathrm{l}$. Specific rotation was:

$$
[\alpha]_{D}^{19^{\circ}}=-33^{\circ}(c=2 \text { in } 2 \mathrm{~N} \text { sulphuric acid }) \text {. }
$$

Partition chromatograms were made with neutralized hydrolysates containing $11.5 \mathrm{~g}$./l. reducing sugars estimated as glucose. Filter papers were irrigated with a mixture of $n$-butanol, ethanol, water and ammonia $(45,5$, $49(\mathrm{v} / \mathrm{v})$ and $1 \%(\mathrm{w} / \mathrm{v})$ respectively), D-Galactose, D-glucose and D-fructose were used as reference sugars. The chromatograms gave a well-defined spot corresponding to D-galactose and a rather weak spot with an $\boldsymbol{R}_{F}$ value of 0.098. The polysaccharide gave no reaction with Seliwanoff's reagent, showing that it contains no appreciable quantities of ketose sugars. Uronic acids were not detected in the polysaccharide $(20 \mathrm{mg}$.) by Tollens's naphthoresorcinol test.

One gram of polysaccharide was hydrolysed by boiling for $3 \mathrm{hr}$. in $2 \mathrm{~N}-\mathrm{H}_{2} \mathrm{SO}_{4}$, freed from sulphate with baryta and made up to $50 \mathrm{ml}$. with water. The solution had a copper-reducing value calculated as glucose of $1 \cdot 154 \mathrm{~g} . / 100 \mathrm{ml}$. On this basis the mean rotation of the component sugars, $[\alpha]_{D}^{18^{\circ}}$, was $+86 \cdot 6^{\circ}$. (Equilibrium value for D-galactose is $+81^{\circ}$.) The reducing value of the hydrolysate calculated as glucose corresponded to $57.7 \%$ of the polysaccharide.

The neutralized hydrolysate $(15 \mathrm{ml}$.) was evaporated in vacuo to a syrup (about $0.5 \mathrm{ml}$.) and treated with glacial acetic acid $(5 \mathrm{ml}$.). The clear solution was seeded with a trace of D-galactose. After standing at $0^{\circ}$ for a few days a crystalline deposit of D-galactose $(0.090 \mathrm{~g} .=30 \%$ of the original polysaccharide) was present, m.p. $162^{\circ}$; mixed melting point with authentic D-galactose (m.p. $164^{\circ}$ ) was $162^{\circ}$.

D-Galactose was determined in the hydrolysate by the method of Hirst, Jones \& Woods (1947). The neutralized hydrolysate $(10 \mathrm{ml}$.) gave D-galactose methylphenylhydrazone $(0 \cdot 1146 \mathrm{~g}$.) corresponding to $45.0 \%$ D-galactose in the original polysaccharide. After recrystallization from pyridine/ethanol $(50 / 50, \mathrm{v} / \mathrm{v})$ mixture, the crystalline product melted at $186^{\circ}$; mixed melting point with authentic D-galactose methylphenylhydrazone (m.p. $188^{\circ}$ ) was $187^{\circ}$.

Crude polysaccharide $(1.0$ g.) in water $(35 \mathrm{ml}$.$) was oxidized with concen-$ trated nitric acid (sp.gr. $1 \cdot 42 ; 15 \mathrm{ml}$.) and gave a crystalline deposit of mucic acid $(0 \cdot 2722$ g. $)$, m.p. $206^{\circ}$. After recrystallization the product melted at $216^{\circ}$ and its melting point was not depressed on admixture with authentic mucic acid (m.p. $216^{\circ}$ ).

\section{Tests for combination between polysaccharide and virus}

Infectivity tests with solutions containing mixtures of tobacco mosaic virus and the polysaccharide from $\boldsymbol{T}$. roseum give results similar to those when the virus is mixed with pancreatic ribonuclease or the phytolacca glycoprotein. That is to say, there is no fixed ratio of inhibitor to virus that wholly neutralizes 
infectivity; the ratio of polysaccharide to virus needed decreases with increasing virus concentration, and concentrated non-infective mixtures become infective when diluted. With ribonuclease and the phytolacca glycoprotein this phenomenon can be attributed to dilution causing non-infective complexes of virus and inhibitor to dissociate, because combination between the virus and these substances in vitro is clearly shown by the separation of paracrystalline precipitates from appropriate mixtures.

There is no visible indication that the $T$. roseum polysaccharide combines with tobacco mosaic virus, and mixtures of the two at widely different ratios, in the presence and absence of salts, have never precipitated. This is no proof that the two fail to combine, for they could form a soluble complex, like that formed when trypsin is mixed with the virus (Kleczkowski, 1944). Evidence that they do not combine was obtained by experiments in which mixtures of virus and polysaccharide were centrifuged at 40,000 r.p.m. for $1 \mathrm{hr}$. Three solutions were centrifuged: (i) contained tobacco mosaic virus at $1 \mathrm{mg} . / \mathrm{ml}$.; (ii) contained polysaccharide at $1 \mathrm{mg} . / \mathrm{ml}$; (iii) contained a mixture of the two at this concentration. Nothing sedimented from the solution of polysaccharide (i), whereas the other two gave birefringent pellets of similar sizes and appearances. After washing with water, the two pellets were dissolved in water, when analyses for carbohydrate and nitrogen showed them both to have the usual values for the virus. Similarly, the supernatant fluid from the centrifuged mixture had the same carbohydrate content as the solution that contained only the polysaccharide, and the two were also equally effective in preventing infection of $N$. glutinosa by tobacco mosaic virus and of beans by tobacco necrosis virus.

We have made no similar tests to demonstrate that trichothecin does not form a soluble complex with tobacco mosaic virus, but its ability to inhibit infections when applied to leaves a day after inoculation with virus seems to render unnecessary any suggestion that inhibition depends on combination between the two.

\section{DISCUSSION}

The main thing that calls for discussion is the mechanism whereby infection is inhibited. Several of our results bear on this problem; they permit the possibilities to be better assessed than previously and suggest a general hypothesis for the action of inhibitors. There seems little doubt that inhibitors directly affect the host plants rather than the viruses. This is strongly implied by the demonstration that the relative efficiency of different inhibitors is determined by the species of the host plant and not by the identity of the virus. It becomes an almost inescapable conclusion from the demonstration that substances which do not combine with viruses in vitro can inhibit infection, for this renders unnecessary any suggestion that hosts differ in behaviour because they differ in their ability to release infective virus from non-infective complexes of virus and inhibitor.

With inhibitors like ribonuclease and the phytolacea glycoprotein, which do combine with the viruses, it is impossible to show that this combination 
plays no part in preventing infection. They may act in a different manner from the inhibitors produced by $\boldsymbol{T}$. roseum, but there are so many similarities between the behaviour of different inhibitors that this seems unlikely. Many substances that are not good inhibitors of infectivity also combine with viruses in vitro. These, like ribonuclease and the phytolacca glycoprotein, are oppositely charged from the viruses at $\mathrm{pH}$ values around 6 (Kleczkowski, 1946), and combination more likely occurs because of this than because of any specific affinity between these substances and viruses. The combination, therefore, is probably irrelevant to inhibition of infectivity, and it has been unfortunate that the inhibitors previously studied do combine with viruses. There is no reason to assume that the inhibitors from $T$. roseum are unique in failing to combine. The inhibitor from yeast also seems not to. Although Takahashi (1946) concluded that it probably inhibits because of 'a reaction involving the inactivator and some group in the virus particle which is necessary for its infectivity', there is no evidence that the two do combine and his electrophoretic measurements suggest that they do not, for the mobility of the virus was unaffected by the presence of the inhibitor.

By analogy with the specific adsorption of bacteriophages on to susceptible bacteria, and from the fact that washing leaves immediately after they are inoculated with viruses does not prevent infection, it is reasonably assumed that a first step in initiating infection is for virus particles to combine with some specific receptors in the host cells. Inhibitors previously studied have been applied simultaneously with, or immediately after, the virus, and their effects have been considered mainly as preventing this postulated first step. They might do this in one of two ways, either by combining with the virus particles or with the essential receptors. The possibility that different types of sites might be concerned in combination does something to account for the fact that substances with widely different compositions act as inhibitors of infectivity, but is a barely adequate explanation. As trichothecin inhibits infection when it is sprayed over leaves a day after they have been inoculated with viruses, there is clearly no reason to assume that inhibitors are substances that interfere only with the first step and act because they have a greater affinity either for viruses or their receptor sites than these have for one another. Instead, it seems more reasonable to postulate that inhibitors are substances whose presence so alters the physiology of the host cells that these no longer support virus multiplication. This view calls for no common attributes among inhibitors, except that they should differ from normal components of cells they affect and, because of this, stimulate the cells to some unusual activity. It adequately explains the fact that extracts from leaves of some plants prevent infection of some other species but not of themselves (Bhargava, 1951; van der Want, 1951).

Trichothecin and its two derivatives, trichothecolone and acetyltrichothecolone, clearly affect the metabolism of plants in which they strongly inhibit infection, for they sometimes cause macroscopic lesions. The failure of these, or other, inhibitors to promote obvious changes in host plants, is no reason to assume they have had no effect; it may mean only that changes in meta- 
bolism have proceeded less far or have been more promptly or completely counteracted. The effects of inhibitors resemble those caused by exposing plants to atmospheres containing $50 \%$ carbon dioxide (Kalmus \& Kassanis, 1944), or to irradiation with ultraviolet light (Bawden \& Kleczkowski, 1952). Both these treatments make bean leaves temporarily refractory to infection with tobacco necrosis virus; in some but not all conditions both treatments also obviously damage the leaves. All such treatments are most reasonably interpreted as acting by diverting the cell metabolism in directions that preclude the customary diversion of protein synthesis to virus formation that follows the introduction of virus particles. During the period of changed metabolism conditions seem such that introduced virus particles are destroyed or rendered non-infective, for although leaves treated with trichothecin, carbon dioxide or ultraviolet light, after a time regain their initial susceptibility to infection, virus introduced during the refractory period does not multiply.

There is no positive evidence for this unitarian hypothesis of inhibitor action, but it covers the facts as now known more simply and adequately than any other. In putting it forward, there is no intention of suggesting that all inhibitors produce the same type of metabolic change in host cells. There is much evidence to show that the readiness with which viruses infect differs greatly with changes in the physiological state of the host. Deviations from the normal metabolism of the host in any of many possible ways might equally upset the sensitive balance necessary for infection and virus multiplication to occur.

\section{REFERENCES}

Bawden, F. C. \& Kleczkowski, A. (1952). Ultra-violet injury to higher plants counteracted by visible light. Nature, Lond. 169, 90.

Bawden, F. C. \& Pirie, N. W. (1936). Experiments on the chemical behaviour of potato virus X. Brit. J. exp. Path. 17, 64.

Bhargava, K. S. (1951). Some properties of four strains of cucumber mosaic virus. Ann. appl. Biol. 38, 377.

Caldwell, J. (1933). The physiology of virus diseases in plants. Ann. appl. Biol. $20,100$.

Freeman, G. G. \& Gill, J. E. (1950). Alkaline hydrolysis of trichothecin. Nature, Lond. 166, 698.

Freeman, G. G. \& Morrison, R. I. (1949a). The isolation and chemical properties of trichothecin, an antifungal substance from Trichothecium roseum Link. Biochem. J. 44, 1.

Freeman, G. G. \& Morrison, R. I. (1949b). Some biological properties of trichothecin, an antifungal substance from Trichothecium roseum Link. J. gen. Microbiol. 3, 60.

Freeman, G. G., Morrison, R. I. \& Michael, S. E. (1949). Metabolic products of Trichothecium roseum Link. Biochem. J. 42, 191.

Gupta, B. M. \& Price, W. C. (1950). Production of plant virus inhibitors by fungi. Phytopathology, 40, 642.

Hills, C. H. \& Vinson, C. G. (1938). Particle size of tobaceo mosaic virus. Res. Bull. Mo. agric. Exp. Sta. no. 286.

HrRst, E. L., JoneS, J. K. N. \& Woods, E. A. (1947). The quantitative determination of galactose, mannose, arabinose and rhamnose. J. chem. Soc. Pt. II, p.1048.

Hockenhulu, D. J. D. \& Herbert, D. (1945). The amylase and maltase of Clostridium acetobutylicum. Biochem. J. 39, 102. 
Johnson, J. (1938). Plant virus inhibitors produced by micro-organisms. Science, 88, 552.

Kalmus, H. \& Kassanis, B. (1944). Reduction by carbon dioxide of susceptibility of beans to tobacco necrosis viruses. Nature, Lond. 154, 641.

Kalmus, H. \& Kassanis, B. (1945). The use of abrasives in the transmission of plant viruses. Ann. appl. Biol. 32, 230.

Kassanis, B. \& KLeczkowski, A. (1948). The isolation and some properties of a virus-inhibiting protein from Phytolacca esculenta. J. gen. Microbiol. 2, 143.

KLECZkowski, A. (1944). Combination of potato virus $\mathrm{X}$ and tobacco mosaic virus with pepsin and trypsin. Biochem. J. 38, 160.

KLeczkowski, A. (1946). Combination between different proteins and between proteins and yeast nucleic acid. Biochem. J. 40,677.

Loring, H. S. (1942). The reversible inactivation of tobacco mosaic virus by crystalline ribonuclease. J. gen. Physiol. 25, 497.

Robertson, A., Smithies, W. R. \& Titrensor, E. (1949). The chemistry of fungi IV. Rosenonolactone from Trichothecium roseum Link. J. chem. Soc. Pt. II p. 879.

Sevag, M. G., Lackman, D. B. \& Smolens, J. (1938). The isolation of the components of streptococcal nucleoproteins in serologically active form. $J . \mathrm{biol}$. Chem. 124, 425.

Somogyi, M. (1937). A reagent for the copper-iodometric determination of very small amounts of sugar. J. biol. Chem. 117, 771 .

Stanley, W. M. (1934). Chemical studies on the virus of tobacco mosaic. I. Some effects of trypsin. Phytopathology, 24, 1055.

Takahashi, W. N. (1942). A virus inactivator from yeast. Science, 95, 586.

Takahashi, W. N. (1946). Properties of a virus inactivator from yeast. Science, $104,377$.

WANT, J. P. H. van der (1951). Investigations on carnation mosaic. Tijdschr. PlZiekt, 57, 72.

Whetzes, H. H. (1909). A fungus living as a parasite upon another fungus. Ont. nat. Sci. Bull. 5, 3.

(Received 27 February 1952)

\begin{abstract}
ADDENDUM
Since submitting our paper for publication we have seen another on the subject by Gupta \& Price (Phytopathology, 1952, 42, 45), in which they conclude, as we do, that filtrates of $T$. roseum inhibit infection by altering host-plant susceptibility and not by acting directly on virus particles. Some of our experiments resemble theirs and the results are generally similar. Apparent discrepancies occur because they used unfractionated filtrates, which were assumed to contain only one inhibitory substance. They describe differences between the sensitivity of certain host plants, but differences between the behaviour of beans and $N$. glutinosa are obscured because tests were made with mixtures of trichothecin and the polysaccharide inhibitor. They also report inhibition of infection in the upper surfaces of bean leaves when the lower surfaces were sprayed with filtrate, an effect for which our results show trichothecin is solely responsible.
\end{abstract}

